\title{
LESSON LEARNED ON MONITORING CULTURAL HERITAGE AT RISK UNDER CLIMATE CHANGES: STRATEGY, TECHNIQUES AND RESULTS
}

\author{
E. Rosina ${ }^{1}$, E. Romoli ${ }^{2}$, A. Pili $^{1}$, M. Suma ${ }^{1}$ \\ ${ }^{1}$ Politecnico di Milano, ABC Dept, Piazza Leonardo da Vinci, 32 elisabetta.rosina@polimi.it, alessandra.pili@polimi.it, \\ marivita.suma@mail.polimi.it \\ ${ }^{2}$ Soprintendenza Archeologia, Belle Arti e Paesaggio per la città metropolitana di Cagliari e le province di Oristano e Sud Sardegna \\ elena.romoli@beniculturali.it
}

KEY WORDS: Moisture, historic masonry, archaeological area, NDT diagnostics, monitoring, rising damp, drainage system, climate change

\begin{abstract}
:
Rising damp is a recurrent cause of damage, and the climatic changes are going towards the increase of humidity (quantity and spreading distribution) in the historic masonry: at $40 / 50^{\circ}$ latitudes, at continental/Mediterranean climatic conditions, the alternance of dry seasons and almost monsoon seasons dramatically affects the distribution of rising damp in porous materials, as well as the water content. Monitoring the presence and distribution of the water is useful to support the choice of the most appropriate intervention, reducing the risk to apply not effective and expensive products and preventing an oversize intervention.

The evaluation of the increase of rising damp is a critical issue for preventing the damages, because the presence of the water can sharply, naturally decrease in the dry seasons, as well as rapidly increases one month or more after the beginning of heavy and constant rain.

The study cases will show the interaction between climate changes and the inadequacy of the present plant for collecting and drain rain in archaeological areas and historic buildings and as well as the nearby infrastructures that should prevent stagnant rain close to the bottom of the masonry.
\end{abstract}

\section{INTRODUCTION}

\subsection{Premise}

The conservation of historic buildings requires to face the technical issue for preserving the historic building materials, as stated in the recent Code for protection of Cultural Heritage, in Italy (D.L. $\left.\mathrm{n}^{\circ} 42,2004\right)$. Art. 29 defines the process of conservation and the plan of conservation is defined as the tool for its achievement: the plan includes the modalities of the use, the required checks and controls for reaching the expected results.

The application of the conservation process of the Cultural Heritage $(\mathrm{CH})$ stresses the valorization as well as the continuous care and maintenance. The valorization requires that design of site respects the issues of cultural contextuality, mitigation of environment effects and use (Della Torre, 2003) (Della Torre, 2010). Among many cause of damages due to the environment, rising damp is one of the major cause of damages in construction underground and over the ground. For that, it is important to assess the presence, quantity and distribution of water in the masonry to define the optimal condition to preserve the structures and materials.

Despite the phenomenon of capillary follows a well-known physic law, the specific features of each structure can affect the sorption capability and capillary rising damp as well.

Moreover, also the climatic variations outside affect the internal climate. As an example, the quasi monsonic heavy rain in late spring caused the increase the humidity content where the rising damp/water leakages are located and consequently the air humidity.

The measurements of $\mathrm{T}$ and $\mathrm{RH}$ of the air is part of the "first aid" diagnostic tools also for detecting the presence of water in the solid masonry, as the values of air RH depend also on the water content and the sharp variations of both are one of the main risk for conservation. Scientific literature recalls the need to assess the "historical climate" for evaluating the risk of damage due to any change (Camuffo et al., 2015).

\subsection{Objectives and strategies}

An extended monitoring of the air measurables (Temperature and Humidity) is needed also to relate the thermal hygrometrical variations registered inside and outside, understand which conditions of the external climate cause interior condition non suitable for the conservation of the materials. Even more, the environment has a direct influence on the microclimate of the archaeological area. As already mentioned, the climate change causes the increase of rain in some months and consequently the increase of the risk of conservation due to the biological and hydrogeological effects. For that the diagnostics and microclimate monitoring has a key role in designing the use of the archaeological areas as well as buildings since the preliminary analysis until the use of the sites (Thompson, 2007) (Huisman et al., 2009) (Rosina et al., 2011).

\subsection{Study cases}

In the further paragraphs, the authors present different typologies of study cases, located in different geographic environments. The control of microclimate variations has been particularly increasing during and after some heavy rains that the regular drainage system could hardly pour out.

The palace of Brera Gallery (Milan) and the Duomo of Mantua had serious damages due to recent storms that in few minutes flooded the gutters and downspouts. In the first case the downspouts were set inside the masonry: the push of the water caused the breakage of the drainpipes and leakages inside the building itself.

In fact, despite their maintenance has been granting the regular flux of rain up to recent time, very abundant rainfalls in June 2011 provoked the break of a downspout: the immediate filling with water the space around the pipe caused the breakage of the 
surrounding wall due to the fast increasing of water pressure. The major risk was that the water could break the wall towards the interior instead of the exterior. In such a case, also the precious paintings inside the room where the damage occurred could be seriously threatened.

In Mantua Duomo, the heavy rain caused almost similar damage, although resulting only in a localized roof leakage. On the other hand, the rain drainage from the roof resulted not enough effective for the increase of heavy rain falls in a short time. As a consequence, the accumulation of the water at the bottom of the masonry increased the water content in the masonry in some zones where the drainage was not fast enough. The following two examples show the hypogeum archaeological sites in Lecco and Cagliari areas, that went under restoration and opened to visits in a recent time. In addition to the risks of rising damp, water leaking and wall breakages, in the archaeological areas the risk of biological attack has been increasing due to the increase of air humidity during the almost monsoon rain. In Lecco zone, the total amount of water due to the fast ice melting in the northern mountains and the continuous heavy rain falls in march 2007 caused the flood of Adda river in the area of Lavello after the restoration of the remains that are underneath the 15th century church. Air monitoring lead the delicate process of controlling the water evaporation and its regulation according to the constant check, that mostly prevented the damage (Rosina et al., 2007).

The study case of the roman tomb is located in Cagliari necropolis. It has been closed for a long time and recently restored together with others of the same zone. At present, the office for the protection of $\mathrm{CH}$ is examining which of them will stand the minor risk for periodically opening and visiting.

\section{METHODS AND TECHNIQUES}

\subsection{Methods}

Monitoring a historic building or an archaeological area is quite different, despite the tools and techniques could be almost the same. Due to the long time of monitoring that is required to have significant data, it is necessary to start measuring as soon as possible. The objective in the first application is checking the main variation of Temperature and Humidity, that could be due to the use, artificial heating and ventilation, active source of water infiltration, the installed plants and their use as well as the natural ventilation and solar irradiation, change of the weather, geomorphology of the environment, etc (Camuffo, 2013) (Rosina, 2018). At the beginning of the study the preliminary monitoring could start with limited resources and focusing on the critical points in similar buildings already monitored.

On the first gathered data, the second phase of the diagnostics can be planned for obtaining a complete set up of the tests to perform.

Monitoring the archaeological area usually is not the first step for the conservation of the tombs and remains. Although the education and orientation of archaeologists is to buried the remains that could not stand the variation of microclimate (at oper air), the excavation itself sometimes do not takes care of the change of air conditions in the meanwhile is occurring. Often, also the following phases of assessment, documentation and finally restoration are not under air monitoring. Monitoring the interior climate and sources of water infiltration is usually required only after the restoration, with the aim to check the possible effects of visitors and/or new/renewed plants (lighting, heating, ventilation etc).

On the contrary, the following cases will show the advantage of the early detection and monitoring, before starting the restoration. The procedures of monitoring follow the direction of the present standards.

Generally speaking, the international standards are a good guidance for the test procedures on both (buildings and archaeological areas despite these second where explicitly not mentioned in the standard). Nevertheless, only recently few standards start to define the complete process of decision, supporting the single techniques with the appropriate references to standards (Rosina et al, 2019a).

As an example, EN 16682:2017 clearly designs the steps that support the decision to investigate the presence and cause of rising damp, for obtaining the most effective results to support the design of the intervention.

Regarding the microclimate measurements, the present italian standard dates 1999 (UNI 10829:1999): despite the optimal description of the test procedures and the use of the results, the standard does not deal with the process of defining goals and resource to invest, as well as how to use the data for designing the next steps, intervention or/and maintenance. An improvement is required, due also the recent climatic changes that affect also the modality of monitoring.

In fact, as anticipated, to ascertain the values of historic $\mathrm{T}$ and $\mathrm{RH}$, is necessary to monitor the microclimate more than one year. The first acceptable release of monitoring data has been considered after 12 months and additional 12 months are considered necessary to understand if the registered phenomena were due to the seasonal variations or exceptional, resulting in some damages. Especially for the hypogeal environments, studies (Sanchez-Moral et al., 2005) (Blasco Lopez et al., 2018) show the existence of "time windows" during which the recorded variations outside and inside are similar, hence opening the sites does no cause sudden changes of the microclimate. The comparison of the values along more than one year helps the identification of these "windows" as well as defining the range of typical values of the microclimate under study, registering any changes that may be harmful.

\subsection{Techniques}

The analysis shows the use and integration of different techniques (IR Thermography; psychrometry; air $\mathrm{T}$ and $\mathrm{RH}$ measurements and recording; gravimetric test for measuring water and salts content) and the obtained data crossing.

The procedures of measurements and data processing followed the present standards (UNI 10829:1999; UNI 9252:1988; UNI EN 16714-1:2016; UNI EN 13187:2000; UNI 11085:2003) and the the best practices already published (Rosina, 2018).

In Brera Palace, the use of IRT and probes for monitoring the air $\mathrm{T}$ and $\mathrm{RH}$ was integrating with gravimetric test (in the internal side where the leakage occurred) and boroscopy/videoscopy of the interior of downspout, along the deadspace from the roof to the cellas, where the basin for gathering drained water is located. The test were performed in the few weeks following the breakage of the downspout, the air condition motoring was prolonged 1 year.

In Mantua Duomo, a punctual monitoring has shown the high and the depth of the rising damp with thermography and drilling analysis in three different moments of the years (dry and after abundant rain, 24 May, 21 June, 25 October 2017). The location of the samples was near the possible causes and in few places where no accidental causes could increase the water content.

Monitoring Lavello archaeological area, in Calolziocorte consisted in two spans (2006-2007 and 2012-2013) of microclimate monitoring, together with thermographic analysis and measurements of water content in the masonry (Rosina, 2012) (Lipovec et al., 2012). 
The preliminary measurements in Lavello started before the yard of restoration in the church, in 1998, because the archaeological areas was discovered in its wholeness only with the remotion of the pavement of the church, dating back to the '50. Therefore only in 1999-2001 a complete archaeological survey, stratigraphy, laser scanning permitted to assess the presence of the remains of three previous churches in the same site, the firs dating back to the romanesque time. The microclimate went under monitoring at the end of the yard, after the restoration of the findings and the construction of the new glass floor that let visitors appreciate the remains underneath it (2006-2013). Condensation, rising damp, biological growth are the main risk of damages. A microclimate monitoring was set for planning the best management of the ruins area to prevent those damages.

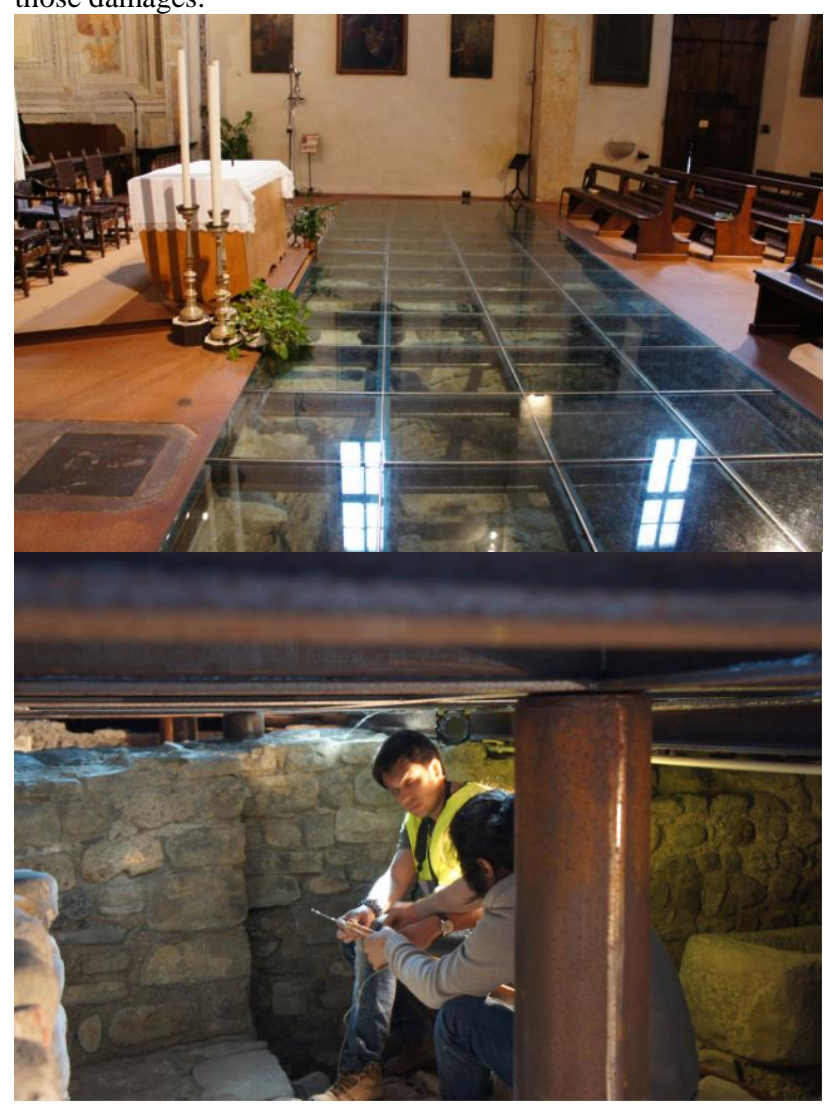

Figure 1. Lavello Convent. Archaeological area inside the Church covered with glass panels. Anemometric tests were performed to understand the ventilation under the covering and to design the correct plant.

Monitoring the Necropolis in Cagliari area (Stiglitz, 2014) (Rosina et al, 2019b) has been lasting 24 months up to now and it is ongoing. It consists on the acquisition of hourly values of air $\mathrm{T}$ and RH, seasonal double measurements by psychrometer, seasonal IRT scanning of all the surface inside the tomb. In addition, after very heavy rain occurred in November 2017, the measures included sampling and measuring the water and salts content.

The results of data crossing allowed the authors to identify the factors inducing the microclimatic variations inside the tomb and the site, how much and how they affect the condition of the conservation.

\section{LESSONS LEARNED FROM THE STUDY CASES}

\subsection{Monitoring of historic buildings}

The study cases are representative of most of the historic buildings in Po Plain, that went under main restoration (partially reconstruction in the case of Brera) after the Second World War. The drainage system has been totally changed in the ' $50 \mathrm{~s}$ : the downspouts were built in the masonry for aesthetic reasons. In Northern Italy, in those years, most of the important historic buildings received the same intervention. Despite of the historic value of these modification, to keep the vertical drainage pipes inside the masonry constitutes a risk of damage in case of heavy rain (figure 2). In the case of Mantua, the Duomo and other historic buildings in the city center have complex structure, with the addition of parts in time that generated an elaborate and intricate drainage system in the roof. The downspouts were partially built in the masonry (especially in the sides along the public transition of people and vehicles), most of them remain on sight. Despite of the periodical maintenance and inspection, due to the complexity of the system is almost impossible to prevent all the possible leakage that could occur in case of heavy rain. In both the cases, a possible suggestion that could improve the velocity of gutter drainage is to apply additional outlet of the collected water as overflow (along the sides that are not over the public passage).

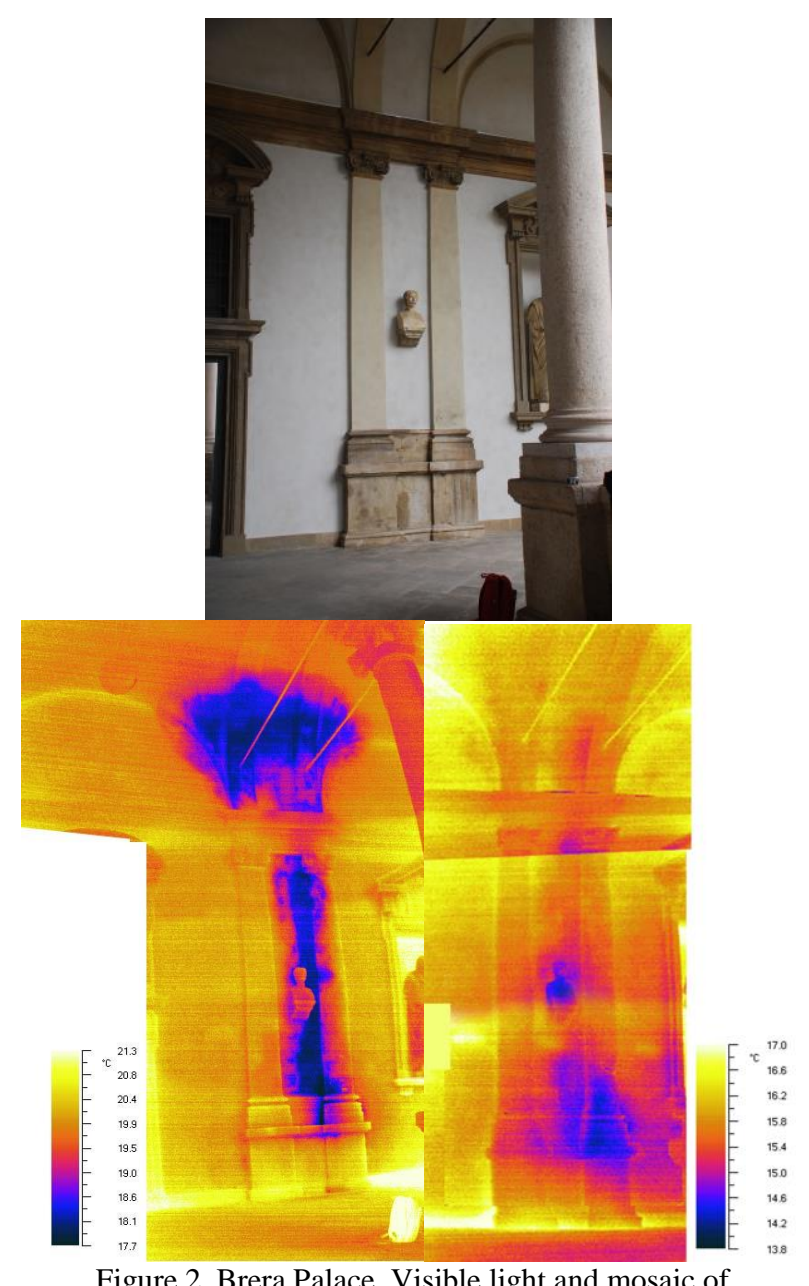

Figure 2. Brera Palace, Visible light and mosaic of thermograms of the wall in front of the broken downpipe. Left side 8 June 2011, right side 10 October 2011.

The results of monitoring at Mantua Duomo showed that the presence of consistent and high rising damp is due to three 
causes: the groundwater in Mantua is very close to the surface of soil, the missing connection of the downspouts to the sewage system and the possible breakage of the sewage system set along the side of the church.

Although the apparent trivial indication, the effectiveness of gutter pipes, downspouts, drainage of the soil around the building, the connection to the sewage seam to play a prominent role to prevent damage of historic buildings and still remains one of the not invasive and low cost intervention that could be more effective to prevent damage.

In fact, the kind of the road pavement along the sides of the building, the connection of the downspouts to the sewage system and the maintenance of the sewage itself are feasible improvement to be done as soon as possible. (fig. 3-6)

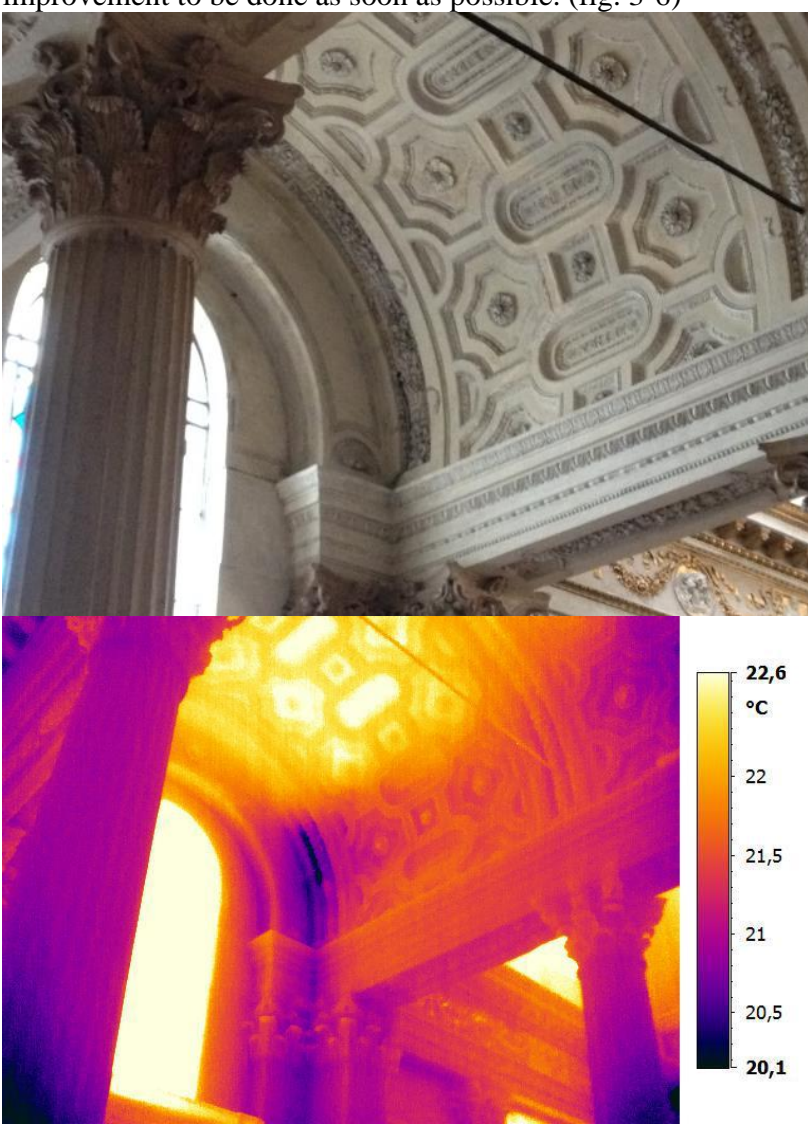

Figure 3. Mantua Duomo. Visible light and Thermogram (24 May 2017) of the vault of the first bay/span, southern nave towards the counter-façade.

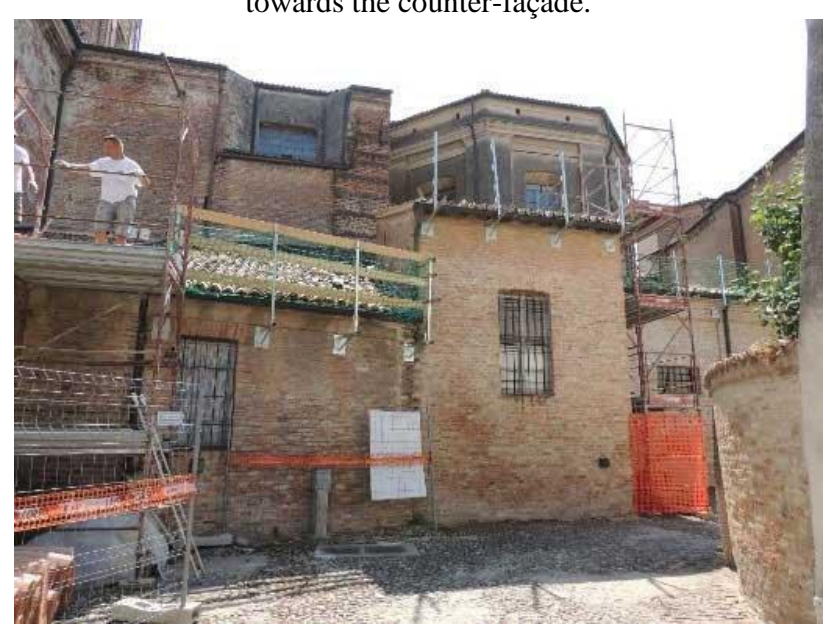

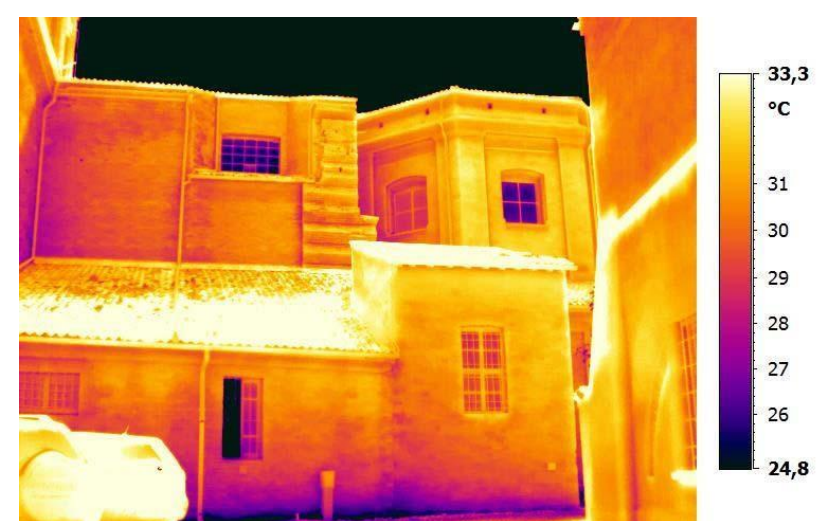

Figure 4. Mantua Duomo. Visible light and Thermogram (24 May 2017) of the North-East façade.

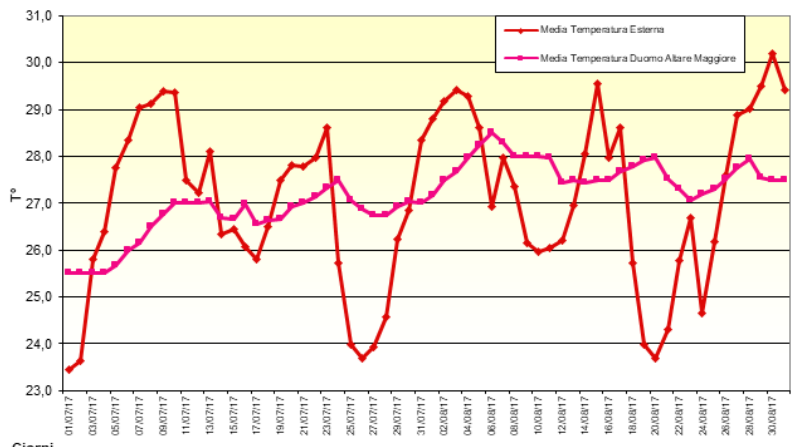

Gio

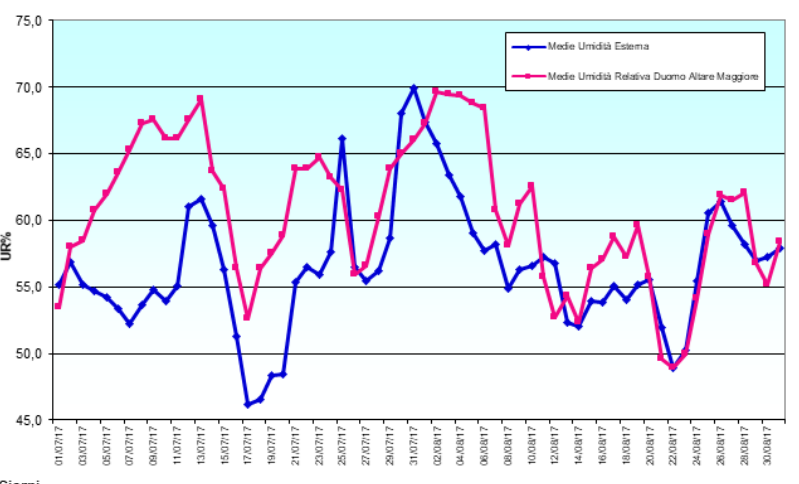

Figure 5. Mantua Duomo. Graphic of the values of the daily average Temperature (yellow) Relative Humidity (blue), July and August 2017.

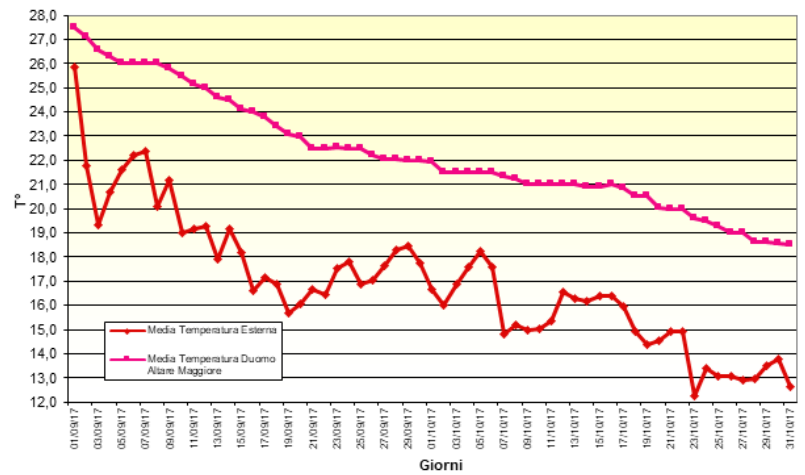




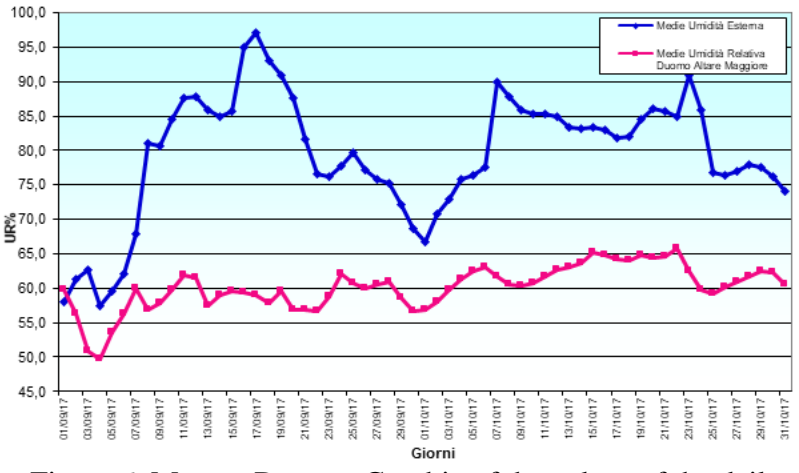

Figure 6. Mantua Duomo. Graphic of the values of the daily average Temperature (yellow) Relative Humidity (blue), September and October 2017.

In both thoss cases monitoring, especially periodically inspection by IRT, is useful to detect leakages just happened (although not yet on sight as stain or wet areas), locate them, provide information on the cause, control the drying in time with the integration or air monitoring.

\subsection{Monitoring archaeological areas}

In Lavello study case, test, analysis and monitoring of the convent went together the monitoring of the archaeological area underneath the floor of the church in 2012-2013.

The aim of the microclimate monitoring was to to verify the effectiveness of the passive ventilation system that was realized in the new steel structure supporting the floor.

Secondarly, the repeated tests aimed to assess the presence, distribution and quantity of water content and its variation according to the level of the water in Adda river flowing few meters far.

The results of the microclimatic monitoring highlighted the highly risky condition due to very high air humidity, the presence of light from the church across the glass slabs, the absence of natural ventilation (the passive ventilation system did not work), the fluctuation of water content in the remains and church masonry due to the variation of the water level outside. Gathering the experimental data of monitoring resulted very helpful for simulating by CFD the real air condition of the hypogeum and to design the most effective active ventilation system, that could adjust the air flux from outside in the way to keep air Humidity below $80 \%$ (Moioli et al., 2013). The threshold of $80 \%$ resulted the most suitable for slowly decrease the extreme high value (95-100\%) resulted after the flood of march 2007 and next.

In the study case of the tomb, the integration of the results allowed the authors to ascertain that the major variations of $\mathrm{T}$ and $\mathrm{RH}$ of the air affect a limited space at the entrance, due to the poor insulation of the wall. In fact, a previous use of the hypogeum caused the demolition of the entrance wall and its reconstruction with brick-lined masonry. The thin wall has different thermal transmittance from the other sides of the tomb, those are excavated directly in the rock. In addition, the entrance side has orientation South-Western and receives sun irradiation since midday to the evening, in the most warm hours of the day.

The distribution of both T and RH has been studied in time and in space by mapping vertical surfaces (IRT) and along horizontal section (psychometry). It resulted homogeneous throughout the year, with a minimum seasonal variation of $2^{\circ} \mathrm{C}$ and Relative Humidity ranging between 90 and $100 \%$.

The main surface thermal anomalies are close to the entrance wall and sometimes near to the vaults of the niches in the entrance room. This anomaly is due to the different thickness of the rock in those parts of the vault. A survey of the thickness and porosity of the rock can be useful to define, in case of heavy rains, the possibility of water infiltration from the ceiling, especially in the niches. The water content of the samples resulted very high, as one of the consequence of the high values of air humidity that was detected in the tomb and possible localized, capillary infiltrations of water from the upper rock bank. Furthermore, the samples taken closer to the entrance are drier than the samples taken in the niches in the rear of the tomb. This could confirm that the entrance wall has poor insulation, when the temperature of air outside increases, the interior surface dries. The insulation of the top of the rock and installation of an air conditioning system should slowly dry the surfaces and the repetition of gravimetric investigations will verify the absence of infiltrations from the rock above if the water content will decrease.

Apart from the zone of the entrance, the microclimatic monitoring has allowed to establish that the daily mean values of $\mathrm{RH}$ and $\mathrm{T}$ are almost independent from the external variations. The temperature values recorded inside are subject to a variation of about $0.5^{\circ} \mathrm{C}$ every 10 days, and show a delay between the peaks and minimum of two months compared to the outside ones. Recently, archaeological excavations in the tomb and outside, in front of the main entrance, have led to wider variations in temperature and slight variations of Relative Humidity, if compared to the ones recorded in the previous year. The total amount of the variation is similar to the previous period, but larger fluctuations are more frequent. Figure 4 and 5 show the values of the daily average air Temperature in the same period of the year (November and December), however in t8he first picture (fig. 7) the Tomb was closed, while in the second (fig. 8) the presence of people influenced the Temperature values.

On the base of the achieved results, opening the tomb will have to consider three main risk factors: the presence of the tourists, the water permeability of the rock and the next stabilization of the microclimate by air conditioning. The first affects the variation of temperature and can increase the quantity of spores causing biological degradation (Sanchez-Moral et al., 2005). The second considers the presence of water infiltration from the top of the tomb. The third will include the design of an insulated entrance for preventing unbalances.

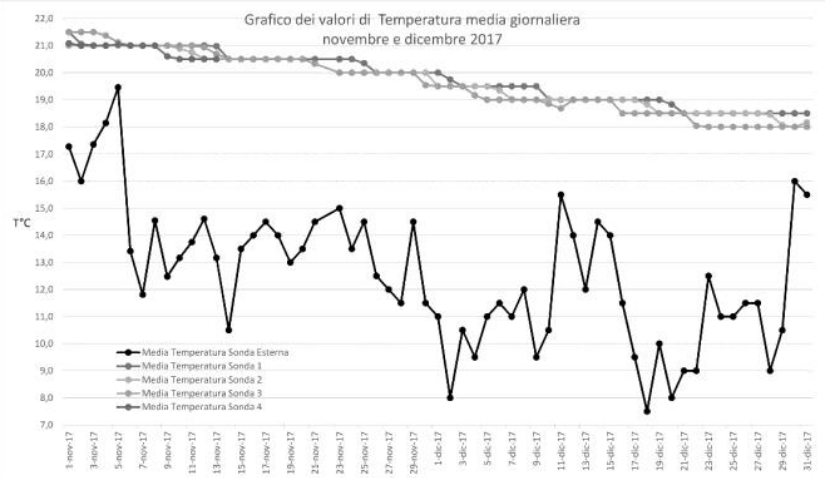

Figure 7. The Tomb in Cagliari, graphic of the values of the daily average Temperature, November and December 2017. During this period the tomb was closed. 


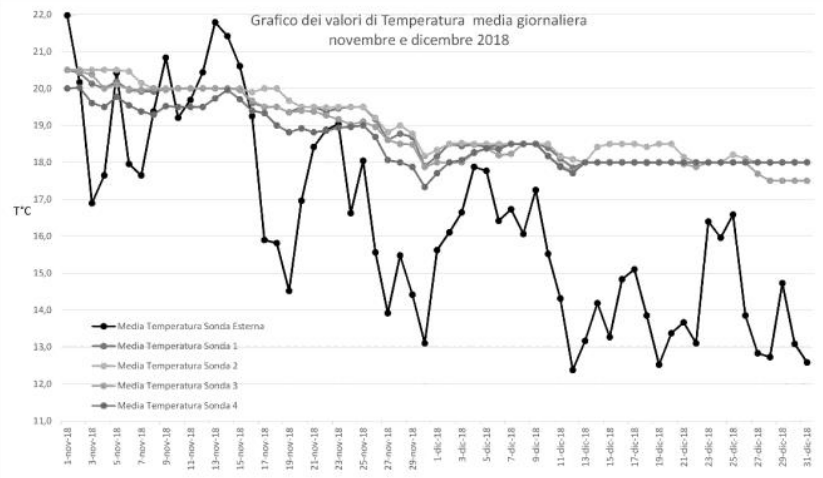

Figure 8. The Tomb in Cagliari, graphic of the values of the daily average Temperature, November and December 2018. During this period, the Tomb was kept partially open for the excavation work (3-5 archaeologists 8-10 hours a day)

\subsection{Systemization of information: Conservation plan and GIS}

The conservation plan was prepared to plan the activities and costs. The information included in it is related to the activities carried out, controls and preventive actions.

At present, the activities carried out concern the archaeological excavation activities; the preventive activities concern the maintenance of the surrounding areas, to avoid interference with the site such as infiltrations of water or infestations, vegetation growth, that could develop roots intruding the rock; finally, the control activities are instrumental and concern the microclimatic monitoring as previously described. In particular, for this last point, the microclimatic monitoring allows the evaluation of the thermo-hygrometric variations during the excavation phases with respect to the previous condition of closure of the tomb. The comparison between the two conditions makes it possible to check the variations with or without people inside and the opening or total closure of the tomb. Experiments on the site planned to study the interactions between the presence of visitors, the new facilities and the internal microclimatic conditions, so as to determine the maximum number of visitors that may be present in the tomb without alterations or harmful changes in microclimatic values. The purpose of these investigations is the definition of the thresholds for the use of the site.

The plan is not prepared on an Information System, therefore the output is presented in the form of cards where all the activities concerning the tombs are recorded.

The use of GIS will be the tool for registering the surface mappings and the carried out activities.

The GIS allows to associate the information to the graphic representation and also to manage the informative data over time. Managing data means obtaining information from its processing, through queries and statistics.

Over the years, various computer models have been developed. To name a few: SIRCoP, SICaR, WGSystem2000-Scheduled Conservation and STR PlaNet-Architectural Heritage. Each with different platforms, contents, functions and purposes. Only two of them (SIRCoP and STR PlaNet) are specific for the Conservation Plan, but lacking the graphic representation. (Pili, 2014)

Instead, the use of GIS for the management of data relating to more precise aspects is more widespread. Miraglia, for example, proposes a model relating to the phenomena of degradation to create a dynamic archive, enables of identifying the various pathologies and assessing their possible variations over time, making it possible to identify any deterioration in the architectural constituent matter. (Miraglia, 2016)

Instead, in a complete and coherent vision with the conservation process, the GIS must make it possible to manage information of all the phases of the process (study, prevention, maintenance, restoration) up to the enhancement activities and use. Therefore, the correct planning of the activities implies the identification of the actors, the times and the costs and the correct planning of the use. GIS is useful for the preparation and implementation of the Conservation Plan it is a method coherent with the aims of the process. The need to apply management information tools to the conservation and enhancement process is inescapable. In this way it is possible to manage the whole process instead of only few steps. (Pili, 2014)

A final remark that has to be taken into account, both for the historic buildings and archaeological areas. With respect to the dissemination of knowledge, a website has to be created for sharing the evolution of activities. The goal is to disseminate the methodology used and to stimulate interest in a site that for many years has remained unknown to the community.

T77his step of the work is ongoing in all the presented study cases.

\subsection{The new use}

The use of the historic buildings, both the Gallery in Milan and the Duomo in Mantua remained the same, as well as the use of the archaeological area underneath the church in Lavello: the Gallery and Duomo receive thousand of visitors any year, the reduction of risks (damages, infiltration, etc.) consists in a better warrant to do not interrupt the activities that are going on inside, as well as to preserve in the best way the building themselves. The Tomb (Salvi, 2013) (Rosina et al., 2019b) (Stiglitz, 2014) is located an archaeological park definitively open to the visit since 2014. It includes many different types of tombs dating back from the Punic to the Roman periods. This entails a greater difficulty in the accessibility of some tombs with so-called "well" entrance, and minor difficulties for other "chamber" tombs although different in height. The advantages of operating in an archaeological park are many, due to the systemic relationship among the different tombs. Therefore, the optimization of the resources results in benefit also for the plan of conservation and maintenance.

The application of updated techniques of assessment and restoration have allowed to achieve the necessary information for evaluating to open some tombs, and how to control and manage of number of visitors. The hypogeal environments has a high thermal inertia due to the thickness and the quality of the rocks. On the contrary the source of the water infiltration is ue to the kind of rock porosity, with scarce possibility to reduce the humidity.

The project of new use provides access only to some tombs that could stand the opening due to their shape and more durable materials. In addition, the design will have some caution to prevent damage and consumption anyway: walkways will have only few points of contact with the ground and will be large enough for the passage of only one person along a circular path. In this way the visitor will be able to observe from a distance the decorated surfaces of the room, having a good visibility of the site and preventing any risk of mechanical and anthropic damage. Special care has been devoted to the design of the entrance room, with the aim to create a double space isolated from the external variation and guarantee accessibility for disabled people.

Solar panel will provide the required energy for the enlightenment and monitoring of microclimate to promptly intervene if the maximum threshold is exceeded. 


\section{CONCLUSIONS}

The analysis of the presented cases resulted that monitoring, in all its different application, is helpful as preliminary assessment, during the damage assessment, after the intervention to check the effectiveness and durability of the results.

Monitoring has three main aims: to define the thresholds for the optimal conservation taking account of the climatic changes; detect and locate the zones under damage and evaluate the effectiveness of proposed intervention.

Due to the prolonging time of monitoring planning this activity since the beginning is mandatory. therefore the use of the plan of conservation is the best tool to control the process of conservation of the good and record the delivered information in an interactive modality with all the stake holders that deal with the conservation of the good (each for its role and responsibility).

By the Plan, the completeness of all the information and the systematic order of their storage will allow to locate the critical zone in a easier way.

As seen in the previous paragraphs, the evaluation of climatic change. Therefore a higher priority has the evaluation of renewing the roofing and drainage system, as well as the elimination of local source of water infiltration from the sourrondings, as gardens, sidewalks, road pavements, sewage, etc.

Simple technical intervention, as the addition of overflows to the eave pipes, remaking waterproof sidewalks around the building, are easy and low cost intervention having a great potential in reducing the possible infiltration of rainfalls.

\section{REFERENCES}

Blasco Lopez, M.F., Recuero Virto, N., Aldas Manzano, J., Garcia-Madariaga, J., 2018. Tourism sustainability in archaeological sites, Journal of Cultural Heritage Management and Sustainable Development, vol. 8, issue 3, 2018, 276-292.

Camuffo, D., 2013. Microclimate for Cultural Heritage: conservation, restoration and maintenance of indoor and outdoor monuments, Elsevier Science, New York, 2013.

Camuffo, D., Bertolin, C., 2015. New insights and meaning of "historic climate" and reburial of archaeological monuments, International colloquium and round table in "modern methods for the protection of newly uncovered archaeological structures. Emergency conservation, protective covering, historical climate and reburial of archaeological monuments", Sofia and Haskovo, 10-13 November 2015, 2015, 113-125.

Della Torre S. (a cura di), 2003. La conservazione programmata del patrimonio storico architettonico, Milano, Guerini e Associati, 2003.

Della Torre S., 2010. Preventiva, integrata e programmata: le logiche coevolutive della conservazione, in Pensare la prevenzione. Manufatti, Usi, Ambienti, Atti del convegno Scienza e Beni Culturali, Bressanone, a cura di Biscontin G. e Driussi G, Venezia, Arcadia ricerche, 67-76.

Huisman, D.J., Borenhout, M., Smit., A., Van Os, B.J.H., Manders, M., 2009. Preservation and monitoring of archaeological sites, Ch. 11, in Degradation of archaeological remains, D.J. Huisman ed., publ. Sdu, 2009, 177-212.
Lipovec, N. Č., Kavur, B., Osojnik, M., Zanier, K., Rosina, E., 2012. Il convento dei Serviti. Un monumento architettonico e archeologico nel cuore di Capodistria. Servitski samostan. Arhitekturni in arheološki spomenik $\mathrm{v}$ osrčju Kopra. The convent of the Servites. An architectural and archaeological monument in the heart of Koper, Poliscript, Milano, 2017.

Miraglia, F., 2016. L'utilizzo del GIS nell'analisi delle patologie di degrado. Nuove opportunità per la tutela del Patrimonio Culturale. Archeomatica. 4. 38-39

Moioli, R., Rosina, E., Rotta, E., 2013. Il sito archeologico della Chiesa di S. Maria del Lavello, in Conservazione $e$ valorizzazione dei siti archeologici, Atti del Convegno Scienza e Beni Culturali, Bressanone 9-12 luglio 2013, Arcadia Ricerche, 2013, 1115-1126.

Pili A., 2014. La gestione del Piano di Conservazione con software GIS e BIM: metodologie confronto, in Quale sostenibilità per il restauro?, Atti del convegno Scienza e Beni Culturali, Bressanone 1-4 luglio 2014, Arcadia Ricerche, 2014, 713-722.

Rosina, E., Suardi, G., 2007. L'adeguamento impiantistico in edifici storici: procedure per il controllo degli effetti sulle superfici interne, Atti della $12^{\circ}$ Conferenza Nazionale AIPND, Milano, ottobre 2007.

Rosina, E., Zanelli, A., Beccarelli, P., Gargano, M., Romoli, E., 2011. New procedures and Materials for Improving Protection of Archaeological area, Materials Evaluations, vol. 69, n.8, 2011, 979-989.

Rosina, E., 2012. Non-destructive investigations: a case study of a convent in Lombardy (Italy), Annales, n, 2, 2012, 9-22.

Rosina, E., 2018. Infrared and Thermal Testing for conservation of Historic Buildings, part 5 in Chapter 18 Infrastructure and Conservation Applications of Infrared and Thermal Testing, in ASNT.

Rosina, E., Suma, M., 2019a. The complexity of conservation of outfitting, historic sites and buildings under everyday uses, in Il patrimonio culturale in mutamento. Le sfide dell'uso, Atti del Convegno Scienza e Beni Culturali, Bressanone 2019, in press.

Rosina, E., Pili, A., Suma, M., Romoli, E., Matta, P., 2019b. Microclimatic monitoring in the archaeological area: from design to new use. The cultural system of an archaeological area in Cagliari, in Atti del Convegno Scienza e Beni Culturali di Bressanone 2019, in press.

Salvi, D., 2013. Cagliari, Tuvixeddu - Quartucciu, Pill'e Matta. Notizie da due necropoli puniche, 2013. A. M. Arruda (ed.). Fenicios e punicos, por terra e mar, Actas do VI Congresso Internacional de Estuos Fenicios e Punicos (Facultade de Letras da Universidade de Lisboa), 25 settembre -1 ottobre 2005, Lisboa 2013, 1101-1117.

Sanchez-Moral, S., Luque, L., Cuezva, S., Soler, V., Benavente, D., Laiz, L., Gonzalez, J.M., Saiz-Jimenez, C., 2005. Deterioration of building materials in Roman catacombs: The influence of visitors, Science of the Total Environment, n 349, 2005, 260-276. 
Stiglitz, A., 2014. Urbanistica di una necropoli: il caso di Tuvixeddu-Tuvumannu a Cagliari (Sardegna), ArcheoArte. Rivista elettronica di Archeologia e Arte, n.3, 2014, 127-146.

Thompson, J., 2007. Conservation and management challenges in a public/private partnership for a large archaeological site (Herculaneum, Italy), Conservation and Management of Archaeological Sites, vol. 8, 2007, 191-204.

\section{Normative e Codici:}

Codice dei Beni Culturali e del Paesaggio, D.L. 22.01.2004 $\mathrm{n}^{\circ} 42$ e modifiche successive.

EN 16682:2017 Conservation of cultural heritage. Methods of measurement of Moisture Content, or Water Content, in materials constituting immovable Cultural Heritage.

Standard for the procedures of Psicrometry and probes to monitor the microclimate UNI 10829:1999 Beni di interesse storico e artistico, Condizioni ambientali di conservazione, Misurazione ed analisi.

Standard for the procedures of Thermography UNI 9252:1988 Isolamento termico. Rilievo e analisi qualitativa delle irregolarità termiche negli involucri degli edifici. Metodo della termografia all'infrarosso; UNI EN 16714-1:2016, Prove non distruttive- Prove termografiche - Parte 1: Principi generali; UNI EN 13187:2000, Prestazione termica degli edifici Rivelazione qualitativa delle irregolarità termiche negli involucri edilizi - Metodo all'infrarosso.

Standard for the procedures of gravimetric test UNI 11085:2003

"Beni Culturali", Materiali lapidei naturali e artificiali. Determinazione del contenuto d'acqua: metodo ponderale. 